\title{
DANZA LA VIDA: NARRATIVAS DE UM PROCESSO CRIATIVO COM IMAGENS DE FRIDA KAHLO
}

\author{
ODAILSO BERTÉ
}

Universidade Federal de Santa Maria

RESUMO O objetivo deste artigo é realizar um estudo sobre o processo criativo do espetáculo e intervenção de dança FeridaCalo (2016), baseado em imagens da pintora mexicana Frida Kahlo. Os modos de uso de imagens nesse processo criativo possibilitam reflexões sobre o poder performativo das imagens e a possibilidade de refuncionalização das imagens para a construção de conhecimentos no ensino de artes. Narrativas de experiências e análises de imagens são os procedimentos metodológicos que viabilizam esta reflexão. Nesse sentido, apontam-se caminhos para a criação artística e o ensino de artes na contemporaneidade, entrelaçando as artes, experiências, narrativas e imagens de diferentes corpos e contextos.

Palavras chave: Corpo. Imagem. Dança performativa. Processo criativo. Frida Kahlo.

\section{ABSTRACT DANZA LA VIDA: NARRATIVES OF A CREATIVE PROCESS WITH IMAGES OF FRIDA KAHLO}

The objective of this article is to perform a study about the creative process of the show and dance intervention FeridaCalo (2016), based on images of Mexican painter Frida Kahlo. The ways of using images in this creative process allow reflections on the performative power of the images and the possibility of refunctionalization of the images for the construction of knowledge in the teaching of the arts. Narratives of experiences and analysis of images are methodological procedures that enable this reflection. In this sense, there are possibilities for artistic creation and the teaching of arts in contemporary society interweaving the arts, experiences, narratives and images of different bodies and contexts.

Keywords: Body. Image. Performative dance. Creative process. Frida Kahlo.

RESUMEN DANZA LA VIDA: NARRATIVAS DE UN PROCESO CREATIVO CON IMÁGENES DE FRIDA KAHLO

El propósito de este artículo es un estudio del proceso creativo del espectáculo y intervención de danza FeridaCalo (2016), basado en imágenes de la pintora mexicana Frida Kahlo. El uso de imágenes en este proceso creativo permite reflexiones sobre el poder performativo de 
las imágenes y la posibilidad de refuncionalización de las imágenes para la construcción del conocimiento en la enseñanza de las artes. Narrativas de experiencias y análisis de imágenes son procedimientos metodológicos con los que se construye esta reflexión. En este sentido, surgen posibilidades para la creación artística y la enseñanza de las artes en la contemporaneidad entrelazando las artes, las experiencias, narrativas y imágenes de diferentes cuerpos y contextos.

Palabras clave: Cuerpo. Imagen. Danza performativa. Proceso creativo. Frida Kahlo.

\section{Dos azuis que movem minhas}

\section{narrativas afetivas}

Cotidianamente, inúmeras narrativas nos tocam, atravessam, impactam - afetam -, independentemente de onde estejamos, da posição que ocupamos e, por vezes, até da nossa vontade. Embora este não seja o objeto central deste artigo, introduzo-o compartilhando a experiência de afeto provocada pelo filme Moonlight: sob a luz do luar (USA, 2017), aqui compreendido como uma forma de narrativa. Esta narrativa filmica é divida em três partes, "Little", "Chiron" e "Black", cada uma detendose em determinados acontecimentos da infância, adolescência e juventude/maioridade de Chiron, personagem vivido pelo jovem ator Alex R. Hibbert. Na primeira parte, "Little", uma pequena cena captura minha atenção:

Figura 1: Frame do filme Moonlight (USA, 2016), direção de Barry Jenkins.

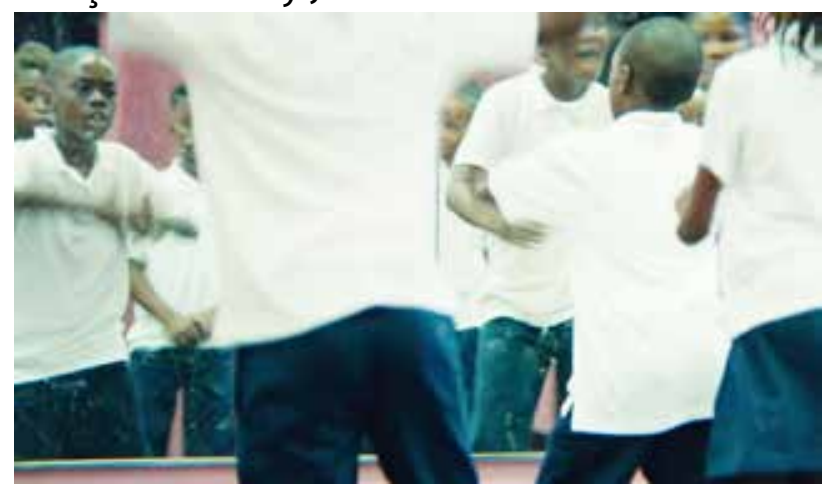

Na figura 1, o pequeno Chiron, um menino negro, de periferia, gay, que vive com a mãe com problemas de drogadição, aparece em um de seus momentos na escola - ambiente terrífico onde essa criança padece com o bullying, especialmente pela questão da homossexualidade, ou melhor, da não virilidade exacerbada e machista como os demais colegas. Esta é uma cena bastante curta, de 22'53" até 23'22", mas é a única onde essa criança aparece feliz dentro do ambiente escolar: na aula de dança. A professora aparece olhando com afeto as crianças dançando livremente em frente ao espelho. Chiron está no centro dos colegas, dançando com desenvoltura, graciosidade, liberdade. Os demais momentos em que aparece rodeado por colegas, está sendo apontado, espancado, humilhado. Chiron olha sua própria imagem no espelho, seus movimentos, sua vida. Mesmo que uniformizados pela vestimenta, as crianças não dançam uma coreografia padronizada e compartilham um momento de respeito entre si, admiração por Chiron, partilha de afetos e de movimentos de dança, celebração que a escola e as aulas de arte/dança poderiam promover cotidianamente nos espaços e tempos do ensinar-aprender.

Independentemente do reconhecimento mundial, com a vitória de melhor filme na cerimônia do Oscar 2017, entre outros prêmios, esse filme, dirigido por Barry Jenkins, me afeta e se atrela à minha história de vida. Na expe- 
riência que fiz, a narrativa filmica impactoume, fazendo-me recordar momentos de minha trajetória escolar, da importância da dança em minha vida, das tristezas vividas por causa do bullying, da minha identidade e masculinidade. As narrativas têm essa potência de impactar, fazer recordar e associar, estagnar, impelir, impedir... Os modos como cada corpo pode reagir, usar, envolver-se com diferentes narrativas são imprevisíveis e não cabem dentro de uma única análise. Nem todos serão alienados, oprimidos, iludidos do mesmo modo que nem todos farão associações, críticas e ressignificações. As experiências de cada corpo, ligadas ao seu contexto e história de vida, podem instaurar a possibilidade de diferentes modos de relação, encontro e confronto com as tantas narrativas que nos chegam a todo o momento.

A pequena narrativa imagética da aula de dança, de Moonlight, entre tantos outros aspectos e questões relevantes que o filme aborda e suscita, possibilitou-me rever aspectos de minha trajetória na dança, de dançarino a coreógrafo, de aluno a professor. Possibilitou, especialmente, introduzir e pensar aspectos em torno do objeto de estudo deste artigo: a trama de narrativas, experiências, corpos e imagens, presente no processo criativo do espetáculo e intervenção de dança FeridaCalo ${ }^{1}$ (2016). Desde os estudos de mestrado e doutorado, entrecruzando dança e cultura visual, narrativas e imagens passaram a ocupar um lugar especial de atenção e crítica dentro dos processos criativos e pedagógicos que tenho desenvolvido, como professor em cursos de graduação em dança (Bacharelado e Licenciatura) e coordenador do Laboratório Investigativo de Criações

1 FeridaCalo é um espetáculo e intervenção e dança, estreado no ano de 2016, baseado em imagens da pintora mexicana Frida Kahlo. Uma síntese da estreia pode ser conferida no vídeo "Especial FeridaCalo", criado pela TV Campus e pelo Laboratório Investigativo de Criações Contemporâneas em Dança (LICCDA), da Universidade Federal de Santa Maria, disponivel no link: <https://www.youtube.com/watch?v=BB7MqN9icT8>.
Contemporâneas em Dança (LICCDA), na Universidade Federal de Santa Maria.

Esse curto trecho da narrativa filmica possibilitou-me pensar sobre: como os procedimentos metodológicos dos processos criativos e pedagógicos em dança, que desenvolvo, se conectam com as experiências dos alunos e dançarinos? Como as experiências e histórias de vida desses corpos - sujeitos imbricam-se a sua criação de movimentos de dança? Como a dança pode ser feita e pensada como uma narrativa de experiências? Essas perguntas esboçam o caminho a ser percorrido no presente texto. Um estudo tramado por imagens, corpos e experiências, atravessado por narrativas que compõem diretamente o objeto de estudo e outras que o tangenciam de modo afetivo, provocativo e memorativo.

Como a narrativa filmica de Moonlight, que surge através da narrativa da peça teatral In Moonlight Black Boys Look Blue, escrita por Tarell Alvin McCraney e também adaptada por ele para o roteiro do filme, o espetáculo e intervenção de dança FeridaCalo surgiu da relação dos dançarinos com imagens do universo pictórico da artista mexicana Frida Kahlo (1907-1954). Na tentativa, não de achar respostas definitivas, mas de refletir em torno do que as perguntas acima suscitam, percorro neste artigo um caminho narrativo no qual conto, descrevo aspectos das experiências vividas ao longo do processo criativo do referido trabalho artístico; apresento e analiso imagens desse percurso e tento enredar reflexões, buscar pistas para pensar o ensino de arte, e especificamente de dança, hoje, com foco no potencial criativo que os corpos têm e podem desenvolver. 0 foco está em perceber e potencializar a capacidade narrativa dos corpos, de narrar suas experiências, contar suas histórias, pensar-fazer uma forma de arte autobiográfica. Ou seja, investigo a possibilidade de fazer - pensar dança a partir de experiências de vida 
dos corpos e de suas experiências com imagens. Neste caso, imagens de Frida Kahlo, que, coincidentemente, e propositalmente escolhida como referência para este trabalho artístico, em diferentes momentos de seu processo criativo, pintou a partir de suas experiências.

Em outra cena comovente, Chiron, o menino que, na narrativa de Moonlight, sorri, na escola, quando dança, aprende a nadar, orientado e amparado por seu amigo Juan, um comercializador de drogas, interpretado pelo ator Mahershala Ali, vencedor do Oscar 2017 de melhor ator coadjuvante por esta atuação. As belíssimas tomadas em close-up fazem o azul do mar encher a tela, como a vida do pequeno Chiron, que parecia uma inundação e ele precisava aprender a nadar para não morrer afogado. Após esse gesto tão (pa)terno, Juan lhe conta uma pequena história da sua infância rebelde em Cuba. Numa noite de lua cheia, Juan corria, descalço, pela rua, atrás de outro menino, quando uma velhinha o interceptou e disse: “Anda correndo por aí, apanhando toda a luz. Sob a luz do luar os meninos negros parecem azuis. Você é azul? É como eu vou te chamar: Azul!" Chiron, que ouviu atento como quem ouve os conselhos de um pai amoroso, pergunta: "Então o seu nome é Azul?" “Não", responde Juan, e segue: "Há um momento na vida em que precisa decidir por si mesmo quem você é. Não pode deixar que ninguém decida isso por você". Na inspiração que emana desse azul, repleto de ternura e encorajamento, o azul do reflexo do luar na linda e sensual pele negra dos corpos de Moonlight, me transporto para o azul cobalto das paredes da Casa Azul de Frida Kahlo. 0 azul que queima, o azul poético, popular e mexicano de suas pinturas, conforme cantam o brasileiro Caetano Veloso e a mexicana Lila Downs, em Burning it Blue, canção tema do filme Frida (USA, 2002). $\mathrm{O}$ azul e as demais tonalidades (in)tensas das imagens criadas por aquele corpo belo e ma- chucado, Frida. Entre tantas narrativas, motivado por esses azuis, eu corpo me envolvo nesse movimento narrativo e reflexivo de escrever, recordar e contar experiências.

\section{Referências do processo criativo de FeridaCalo}

Conforme a reflexão já iniciada em outro estudo (BERTÉ, 2016), as afecções e experiências que a vida e obras de Frida Kahlo me suscitam têm movido processos criativos e pedagógicos em dança. A vontade e a necessidade de dançar Frida, narrar em movimentos - gestos - ações os desconfortos e ousadias que suas imagens me provocam, irrompeu com uma coreografia chamada Kahlo no Corpo (2009), junto a um grupo experimental de dança-teatro, a Cia. Sarx de Dança-teatro, na cidade de Santo Ângelo, Rio Grande do Sul, Brasil. Mas isso foi a ponta do iceberg daquilo que eu, corpo afetado e (co)movido pelo corpo-Frida e suas imagens de sangue e flor, ainda pretendia fazer. Frida, uma mulher que pinta o corpo vestido e despido, chorando e sangrando, cativo e altivo, mobiliza-me um tipo de admiração que, em vez de deter-se na valoração de culto de suas imagens, busca profanar a suposta sacralidade da arte, produzindo situações, vivências com outros corpos nas quais as imagens são tocadas, trocadas, usadas e realizadas de outras formas. Narrativas, imagens e experiências compartilhadas em fazeres críticos, criativos e performativos.

Vejo nessas possibilidades uma potência da arte contemporânea em enfatizar a subjetividade, a experiência e as ações - o trabalho - do artista na criação da obra. Talvez mais que a obra, a exuberância das tentativas, erros, acertos, possibilidades de obra que ficam pelo caminho e que o processo criativo (SALLES, 2014) deixa a ver, sejam o que pode transformar o corpo artista em seu fazer. Vejo, também, o público que, ao compartilhar essas potências com 
o artista, contribui com o processo criativo com seus modos de ver, interpretar e significar. Assim acontecem diferentes e inusitadas experiências estéticas. Tenho pensado em processos de criação que não apresentam ao público coisas ocas, sem vida, a serem cultuadas como objetos isolados da esfera comum do uso, relação, contato, conforme reflete Agamben (2007), ao destacar a importância da profanação - o toque, o jogo, o uso - de objetos sacralizados, fazendo-os retornar para a esfera comum.

Nas trilhas e compreensões da arte contemporânea, parte das motivações em desenvolver processos de criação em dança a partir de imagens, vem da compreensão de pós-produção articulada por Bourriaud (2009). As possibilidades de usar, refuncionalizar, ressignificar, editar e exceder objetos e imagens já existentes, a exemplo do que faz o DJ (Disc Jockey) com músicas já existentes, possibilidades que são infinitas e estimulantes. De modo semeIhante, temos pensado, no Laboratório Investigativo de Criações Contemporâneas em Dança (LICCDA), o uso das imagens de Frida Kahlo. Como produzir outras formas, (trans)formar, ressignificar imagens já existentes, tão difundidas a nivel mundial, conferindo-lhes outras formas de ser, se apresentar e de serem vistas?

A essa reflexão da pós-produção, aproximo a reflexão de Katz (1998), quando pensa o coreógrafo com um DJ de movimentos. A figura do coreógrafo como o gênio que cria passos de dança e os transmite aos bailarinos para serem decorados e reproduzidos, fica quase sem sentido quando o pensamos como um DJ. Tratase do coreógrafo como sujeito, corpo artista, que vai trabalhar com os movimentos, gestos, ações, criados por outros corpos, pelos dançarinos ou intérpretes-criadores - como temos preferido chamar na dança contemporânea. 0 coreógrafo como um corpo estimulador que lança desafios criativos para os corpos dançarinos pensarem e construírem movimento, ou, dito de outra forma, moverem ideias corpo afora. 0 coreógrafo como um organizador de narrativas, que tanto interpela à criação como reconfigura o material criado pelos demais corpos que, dessa forma, se fazem coautores no processo criativo. O coreógrafo não é um sujeito que opera exclusivamente sobre o movimento criado por outros corpos. Cada corpo é e pode ser coreógrafo DJ de si mesmo, pensando, editando, selecionando e decidindo como mostrar seus movimentos.

Exemplo disso tem sido o trabalho da coreógrafa alemã Pina Bausch (1940-2009), junto à Cia Wuppertal Tanztheater, da cidade de Wuppertal, Alemanha. Desde 1973, quando passou a trabalhar com esse grupo, Pina foi descobrindo e construindo um peculiar procedimento de criação de dança. Em vez de dar passos prontos, ela fazia perguntas aos dançarinos. Perguntas que os remetiam a experiências, momentos e situações de suas histórias de vida, afetos, memórias, recordações. Perguntas que os faziam pensar sobre as sensações que determinadas experiências, por exemplo, de amor, medo, perda, saudade, alegria, entre outras, lhes haviam causado e como era revisitá-las no processo criativo. As respostas às perguntas de Pina eram, na sua maioria, em forma de movimentos, outras com pequenos textos, sons, uso de objetos. Mas o foco era centrado no movimento, na ação, na gestualidade. Pina, além de estimular a criação com as perguntas, desenvolvia posteriormente um trabalho de seleção, edição, junção, recortes do material criado pelos dançarinos, definindo assim o que iria constituir o espetáculo.

Essas têm sido algumas das principais referências e fundamentações para os processos criativos e investigativos do LICCDA, nesse momento, centrados em torno das imagens de Frida Kahlo. Uma compreensão que nos tem guiado no processo criativo de FeridaCalo é que, a narrativa - dança que empreendemos não é a 
narrativa dos libretos do balé clássico que traçavam toda a história contada pelo balé. Não é a narrativa dos cenários e dos pesados figurinos que, independentemente dos movimentos (passos codificados do balé), eram quem contava a história, deixando os passos como meras ilustrações da música e os corpos como manequins a transportar trajes glamourosos. Não é também a narrativa do vocabulário de passos do balé, que independentemente da história, Bela Adormecida, Dom Quixote, Gisele, Paquita ou qualquer outra, os passos/movimentos são sempre os mesmos, caindo num lugar onde o movimento - ação do corpo que dança - parece não importar, pois a pesada narrativa do conjunto libreto, música, cenário e figurino, é o que prevalece.

Já os movimentos modernos da dança, com Isadora Duncan, Martha Graham, José Limón (Estados Unidos), Rudof Laban, Mary Wigman e Kurt Jooss (Alemanha), Angel e Klauss Vianna (Brasil), e, especialmente os pós-modernos e contemporâneos, como Merce Cunningham (Estados Unidos), Pina Bausch e Johann Kresnik (Alemanha) e o Grupo Cena 11 (Brasil), entre muitos outros artistas, têm enfatizado, com diferentes abordagens, a centralidade do movimento antes de qualquer outro elemento cênico, ou da própria organização cênica para a apresentação da obra. Louppe (2012) tem discutido a poética da dança contemporânea, o movimento e o lugar, ou não, da representação. Katz (2004) enfatiza com precisão que o que possibilita à dança ser contemporânea é a pergunta que ela faz ao público. Ou seja, como a organização dos elementos que estão em relação ao corpo em movimento questiona, perturba, provoca, desinstala, afeta o espectador. Desde a pergunta de "por que o corpo faz o que faz?" em cena, a tantas outras que possam emergir da relação entre o corpo dançarino e o corpo espectador, pode residir um caráter que faz dessa dança contemporânea, uma dança imbricada ao que os corpos vivem, fazem, pensam. Dança - ideia(s) que o corpo move, organiza e dá a ver como narrativa móvel e semovente, compartilhada e passivel de ser transformada pela percepção e interpretação dos corpos que a veem.

Junto dessas referências está Frida Kahlo não desempenhando apenas um papel de musa inspiradora para o trabalho artístico $\mathrm{Fe}$ ridaCalo. As imagens de Frida não foram apenas modelos que pousaram para os olhares curiosos dos intérpretes-criadores do LICCDA. As imagens agiram como sujeitos dotados de desejos (MITCHELL, 2015), indicando-nos caminhos para descobrir aspectos instigantes do processo criativo de Frida Kahlo. No decorrer do processo criativo de FeridaCalo, o processo criativo de Frida foi ganhando relevância no sentido de interpelar o nosso fazer artístico em torno das imagens da pintora. Era como se as imagens - que nos levaram a leituras, informações e documentos de processo da própria Frida - com desejos próprios, passassem a nos questionar: que tipo de uso vocês intentam fazer comigo? Trata-se de uma simples representação ou encenação da imagem? Quais os processos que me trouxeram à vida? Como Frida criava suas imagens? Como pensar as imagens de Frida como narrativas de experiências?

\section{Experiência e imagem no processo criativo de Frida Kahlo}

Em muitos de seus quadros, Frida Kahlo se pintou. O corpo em dor é uma narrativa recorrente em seu trabalho. Suas experiências perpassam suas obras, declarando um modo de fazer arte que tem o corpo como protagonista. Rico (2004, p. 23, tradução nossa) constrói sua argumentação destacando que "nas obras de Frida Kahlo encontramos a imagem do corpo que funciona como centro e mestre do espaço, a partir do qual tudo parece estar em uma 
inquietante dialética do eu-ao-outro".2 Relacionando a obra da artista com a fenomenologia de Merleau-Ponty, esta autora propõe que, ao longo de quase toda a produção de Frida Kahlo, o corpo, concreto e imaginado, está presente, tecendo uma trama de figuras e situações provocadoras. Por sua vez, estas narrativas podem despertar no espectador diferentes estados de confusão e angústia.

A "profunda consciência que a artista tem do corpo"3 (RICO, 2004, p. 25, tradução nossa), possibilita pensarmos em seu processo de criação artística como uma forma de enfrentamento, identificação e talvez até de sublimação de suas dores. Dores do acidente automobilístico, da sua coluna fraturada, das cirurgias, da sua perna mais curta e enfraquecida pela poliomielite (paralisia infantil), dos sofrimentos e prazeres amorosos, tanto de sua relação com o pintor Diego Rivera (1886-1957) como com outros homens e mulheres. Conforme analisa Monsiváis (2004, p. 18, tradução nossa), entre 1944 e 1954, Frida Kahlo fez o seu Diário, criando uma forma de "exorcismo contra a dor que declara o corpo jacente, o confinamento em hospitais e as operações, entre elas a amputação da perna". ${ }^{4}$ Tanto o Diário como muitas de suas pinturas podem ser vistos como "espaço de transfiguração da dor em expressividade, da rotina de sofrimento em afã criativo"5 (MONSIVÁIS, 2004, p. 18, tradução nossa). Uma fusão de pintura e escritura, desejo e redenção, como se com suas obras Frida Kahlo pudesse se refugiar nas imagens.

2 No original: "En las obras de Frida Kahlo encontramos la imágen del cuerpo que funciona como centro y maestro del espacio, a partir del cual todo parece entrar en una inquietante dialéctica del 'Yo-al-outro'".

3 No original: "[...] la profunda conciencia que la artista tiene del cuerpo [...]".

4 No original: "[...] exorcismo contra el dolor, que declara el cuerpo yacente, el confinamiento en hospitales, y las operaciones, entre ellas la amputación de la pierna [...]".

5 No original: “[...], espacio de transfiguración del dolor en expresividad, de la rutina de la sufridera en afán creativo [...]".
Em uma de suas poéticas declarações a Diego Rivera, em seu Diário, quase como um salmo ou cântico de amor, Frida tece uma espécie de litania do corpo:

[...] Era sede de muitos anos retida em nosso corpo. [...] Tudo cercava o milagre vegetal da paisagem de teu corpo. [...] De ti até minhas mãos, percorro todo teu corpo, e estou contigo um minuto e estou comigo um momento. [...] 0 milagre vegetal de meu corpo torna-se no teu a natureza inteira. [...] Penetro no sexo da terra inteira, o seu calor me abrasa e por todo meu corpo roça o frescor das folhas macias. [...] E nesse momento ainda repleto de sensações, as minhas mãos estão mergulhadas em laranjas, e meu corpo se sente envolvido pelos teus braços. (KAHLO, 2015, p. 202-203)

Rivera (2007, p. 233-234, tradução nossa), que foi esposo da artista por duas vezes, destacou que Frida é "o único exemplo da história da arte, de alguém que se desgarrou, no seio e no coração, para dizer a verdade biológica do que sente neles, e foi possuída da razão-imaginação que é mais rápida que a luz". ${ }^{6}$ Esse reconhecimento, saudoso e apaixonado de Diego, salienta o caráter corporal da pintora em suas imagens, sua verdade biológica, visivel no seu apreço e uso de imagens da anatomia e da botânica em seu processo criativo.

Assim, a imagem do corpo, centro da figuração, se converte no receptáculo de toda a visibilidade. Ele é o princípio e o fim de seu universo e através de sua imagem ela modela o conjunto de suas criações como algo que forma parte de sua própria definição, como um anexo de si mesma, como uma prolongação de seu ser.? (RICO, 2004, p. 27, tradução nossa).

6 No original: “[...] el único ejemplo, en la historia del arte, de alguien que se desgarró en el seno y el corazón para decir la verdad biológica de lo que siente en ellos, y poseída de la razón-imaginación que es más rápida que la luz [...]."

7 No original: "Así, la imágen del cuerpo, centro de la figuración, se convierte en el receptáculo de toda la visibilidad. Él es el principio y el fin de su universo, a través de su imágen ella modela el conjunto de sus creaciones como algo que forma parte de su propria definición, como un anexo de sí misma, como una prolongación de su ser". 
Como enfatiza Herrera (2015, p. 276), Frida se inspirava em sua realidade para realizar suas obras e "criá-las era apenas parte de e não mais importante do que - criar e ser Frida Kahlo". A própria pintora expressou: “Eu pintei a minha própria realidade" (HERRERA, 2015, p. 323), o que possibilita interpretarmos em sua arte uma forma de apropriação da experiência vivida, ou seja, um modo de narrativa e expressão artística inspirado nos acontecimentos. Um fazer artístico baseado nos modos como ela percebia, interpretava e transfigurava a sua realidade em forma de narrativas visuais.

“Em imagens de si mesma descalça, sem cabeça, rachada, aberta, sangrando, ela transformava a dor nas imagens mais dramáticas possiveis, de modo a imprimir nos outros a intensidade de seu próprio sofrimento", enfatiza Herrera (2015, p. 420). A inter-relação arte, corpo e experiência é um importante aspecto que me auxilia a refletir sobre o processo criativo de Frida Kahlo, tendo em vista a proposição e a investigação de processos criativos em dança. A pungência com que sua vida atravessa sua arte, e vice-versa, eriça-me os sentidos, produzindo diferentes formas de interpretação não centradas apenas na contemplação das obras - objetos de arte. Como suas narrativas (pinturas, desenhos, cartas, diário), o seu cotidiano, suas paixões, sua convalescência, seus corsets ortopédicos, seus vestidos, suas flores e enfeites - sua cultura visual é atraente, persuasiva e provocadora de insinuações, significações e mitologizações. A moda Frida Kahlo, o conceito Frida Kahlo, o contexto Frida Kahlo conformam um complexo de elementos que extrapolam os limites da arte, da estética (teoria da arte), das paredes dos museus.

Monsiváis (2004) reflete acerca das tantas imagens possiveis dessa artista e do culto para-cristão, nacionalista e de gênero, também chamado de fridomania, que a converte em santa dolorosa, símbolo da identidade mexicana e heroína feminista. Frida Kahlo, um misto de narrativas, imagem icônica propagada, usada e transformada, mundialmente, por diferentes sistemas, espaços, sujeitos. Uma muIher que "encarava com uma atitude estética o ato de se vestir" (HERRERA, 2015, p. 141), trajando-se de índia tehuana, vestimenta autóctone que ela exibia com orgulho e requinte, no período histórico da primeira metade do século $X X$, em que a imagem indígena era resgatada como símbolo nacionalista, em que arquétipos culturais se entrelaçam aos ideais pós-revolucionários mexicanos. Ela também gostava de se vestir de modo, tradicionalmente, mais masculino, usando calças, realçando os pelos sobre os lábios (bigode), criando uma "complexa mescla de feminilidade tradicional e de rechaço a esta característica"8 (BARTRA, 2004, p. 53, tradução nossa).

Em sua época, Frida Kahlo era a Senhora Rivera, a esposa do grande gênio muralista Diego Rivera, afamado mundialmente. Hoje, o que vemos é "Frida em primeiro termo, e Frida e Diego em segundo lugar"9 (MONSIVÁIS, 2004, p. 11, tradução nossa). Lavín (2007, p. 236, tradução nossa) pergunta: "Há alguma outra figura da arte mexicana a quem chamamos por seu primeiro nome?"10 Convertida em um dos principais símbolos do México, sua imagem domina as paradas da arte e da cultura pop, alcançando diversificados recantos populares, multiplicada em incontáveis formas artesanais de reprodução. Frida Kahlo pode servir de exemplo ao fenômeno da estetização cultural (AGUIRRE, 2011), o desbordamento de elementos estéticos do campo das artes para diversos âmbitos da cultura. Exposições do Brasil à Coreia do Sul, cruzando os continentes de pon-

8 No original: “[...] compleja mezcla de feminidad tradicional y de rechazo a esta característica [...]".

9 No original: "Frida en primer término, y Frida y Diego en segundo lugar, [...]".

10 No original: "Hay alguna otra figura del arte mexicano a la que llamemos por su primer nombre?" 
ta a ponta, filas e ingressos esgotados, Frida é esperada e aclamada. Em feiras de artesanato; lojas de bijuterias, roupas, calçados, acessórios, bolsas; tema de incontáveis livros e pesquisas acadêmicas, de espetáculos de dança e de teatro, de ópera, cinema e composições musicais; Frida Kahlo é moda, é cult, é kitsch, é top, é pop.

São essas características de Frida Kahlo que me fazem pensá-la dentro do que tenho compreendido com o neologismo contempop (BERTÉ, 2015). Contemporâneo e pop. Contemporâneo, próximo da compreensão de Agamben (2009), quando este se refere a uma relação de aderência e de distância com o próprio tempo; de não se deixar cegar pelas luzes do próprio tempo, buscando perceber e interpretar permanentemente o que está no escuro, invisibilizado, fora dos holofotes. Pop, próximo das compreensões de Shusterman (1998), Certeau (2012) e Giroux (1999), quando estas possibilitam refletir acerca da práxis sociocultural e política em torno das práticas e estéticas populares de uso, transformação e ressignificação de produtos e imagens extremamente popularizados, e que tocam os corpos de modo afetivo, impactando e transformando suas experiências.

Por esses caminhos, penso Frida Kahlo como um fenômeno contempop, uma artista com uma produção artística e cultural realizada num contexto, tempo e espaço específicos, mas que se desloca desse tempo e espaço, seja pela insubordinação aos padrões do movimento muralista, que imperava à época, mesmo tendo admirado e sido casada com um dos principais muralistas, Diego Rivera; seja por seus movimentos afetivos e sexuais que não se encaixavam perfeitamente no feminismo e nem no patriarcalismo e, sim, desconcertam ambos; e, ainda, pelo fato de hoje ser uma artista reconhecida e com obras superavaliadas no sistema das artes e, concomitan- temente, ser uma popstar tão famosa, querida e criticada, quanto a cantora norte-americana Madonna, que, diga-se de passagem, é uma das suas maiores admiradoras. Seja através de obras originais ou das tantas imagens reproduzidas e transformadas em milhares de outros produtos, Frida ocupa paredes, corpos e corações, de museus, de famosos e de anônimos. Vejo Frida como corpo - imagem contempop, um fenômeno cultural, conceito e conjunto de aspectos que me afeta, impacta minhas experiências e se faz referência para o processo criativo do trabalho de dança FeridaCalo, objeto deste artigo. A potência contempop das imagens de Frida remete a mim e aos demais integrantes do LICCDA a pensar acerca de seu processo criativo, de como ela deu vida a essas imagens que a tornam tanto prestigiada como criticada, na contemporaneidade, por críticos, celebridades e anônimos.

Conforme Rico (2004, p. 24, tradução nossa), para Frida "o ato de pintar se situa no delicado limite da experiência do corpo e do mundo"."11 Um modo de fazer artístico que, ao basear-se na realidade, não narra factualmente a experiência e tampouco a transmuta de forma onírica. Muitas das obras de Frida foram inspiradas em sua realidade - conjunto de experiências -, mas não são as experiências em si e sim reconstruções dessas. Compreendo o trabalho de Frida como ação criadora arraigada na experiência do corpo - relação corpo-ambiente - com o que isso tem de interno e externo, subjetivo e objetivo, mental e sensório-motor - indissociada, sem separação ou hierarquia. Em uma carta a Carlos Chávez, em 1939, transcrita por Tibol (2004), Frida disse que, para encontrar satisfação e prazer perante os percalços da enfermidade, encontrou na pintura seu meio de expressão:

11 No original: “[...] el acto de pintar se sitúa en el delicado límite de la experiencia del cuerpo y del mundo [...]". 
[...] meus temas sempre foram minhas sensações, meus estados de espírito e as reações profundas que a vida tem causado dentro de mim [...] materializei tudo isso em retratos de mim mesma [...] para expressar o que sentia a meu respeito e a respeito do que tinha diante de mim. (TIBOL, 2004, p. 105)

A relação corpo e ambiente, como argumenta Greiner (2005, p. 104), opera em um movimento de mão dupla, não é só a cultura que influencia o corpo e tampouco apenas o corpo que influencia a cultura, pois "trata-se de uma espécie de contaminação simultânea entre dois sistemas sígnicos onde ambos trocam informações de modo a evoluir em processos, juntos". $A$ arte de Frida "era produto de seu temperamento, vida e lugar" (HERRERA, 2015, p. 314), era sua maneira de dialogar com a realidade vivida, presenciada, experienciada. O fazer artístico de Frida, um fazer autodidata que ela não quis afiliar a nenhuma escola ou técnica tradicional, não imita as situações e acontecimentos que ela viveu. Com Hércoles (2006, p. 108), entendo que "não cabe à arte completar as lacunas da realidade, mas sim, propor outras realidades possiveis, onde as possibilidades de significação se mantenham em aberto". Frida é corpo que materializou na pintura as sensações e reações que sua realidade lhe causava.

Bartra (2004, p. 43, tradução nossa), propõe que "Frida Kahlo tão somente se expressava em sua pintura, e que criava nova realidade a partir de sua experiência para a arte"."12 Tenho compreendido que nas interações corpo e ambiente ocorrem processos de troca de experiência e que aquilo que percebemos é determinado pelo que fazemos. Argumentando que a percepção é um modo do corpo pensar/ explorar o mundo, Greiner (2005) propõe que ter uma experiência é se confrontar com um modo possivel do mundo.

12 No original: “[...] Frida Kahlo tan sólo se expresaba en su pintura, y que creaba una nueva realidad a partir de su experiencia hacia el arte".
As experiências são frutos de nossos corpos (aparato motor e perceptual, capacidades mentais, fluxo emocional, etc.), de nossas interações com nosso ambiente através das ações de se mover, manipular objetos, comer e de nossas relações com outras pessoas dentro da nossa cultura (em termos sociais, políticos, econômicos e religiosos) e fora dela. (KATZ; GREINER, 2005, p. 132)

Ao desenvolver seu processo criativo com base em suas experiências, Frida explicita a imbricação arte, corpo e experiência, que já existe independentemente disso ser mais ou menos explícito tematicamente nas obras de arte. O realismo de Frida não é representativo, mas transformativo. Por exemplo, a amamentação no quadro Mi Nana y Yo (1937) e o homicídio em Unos Cuantos Piquetitos (1953) não são fotografias documentais dos fatos ocorridos. São formas de reorganização metafórica e narrativa (que se referem aos fatos, mas não são eles) que Frida-corpo-artista elabora em meio aos modos como as experiências perduram, a desestabilizam e arrebatam. Ao encarar suas vivências, tendo-as como referência para a criação artística, Frida as realiza de outras formas, reposicionando -as e excedendo-as.

Um instigante aspecto do processo criativo da pintora, encontrado através do uso de suas imagens em nosso processo criativo de dança, que explicita essa habilidade de criar com as experiências do corpo e que se assemelha com o fazer artístico de FeridaCalo, é o modo como a própria Frida usava imagens em suas criações. Seu pai, Guillermo Kahlo, era um reconhecido fotógrafo e pode ter influenciado a cultura visual da filha com a fotografia, especialmente como os muitos autorretratos que ele, Guillermo, fazia. Frida tornou-se amiga e foi fotografada por diferentes e renomados fotógrafos, entre eles Nickolas Muray, Lola Álvarez Bravo, Gisèle Freund. Entre suas fotos mais icônicas, disseminadas e conhecidas, estão aquelas fei- 
tas por esses fotógrafos. É conhecido também, como comenta Herrera (2015), o gosto de Frida por diferentes gêneros de cinema, teatro, dança e artes populares. Sua Casa Azul, hoje o Museu Frida Kahlo, ainda abriga as muitas peças de artesanato, pinturas, utensílios domésticos, bibelôs e a coleção de retábulos ou ex-votos que ela montou e zelou primorosamente. Estes elementos de afeto, parte de sua cultura visual, de suas experiências corporais, constituíram seu processo criativo, influenciando escolhas e procedimentos de pintura, alternância e mistura de cores, um estilo mutante chamado por diferentes críticos e estudiosos de primitivismo (HERRERA, 2015), realismo (RIVERA, 2007), popular (GÓMEZ, 2006), surrealista (LOZANO, 2007; TIBOL, 1993; DEL CONDE, 2002, naïf (ESTRADA, 2013) e surrealista-naïf (DEL CONDE, 2002.
Não me detenho em definições e classificações acerca do estilo, método ou escola à qual Frida Kahlo se filiou e supostamente seguiu, visto que ela mesma expressou, em diferentes momentos, não ser surrealista, pois não pintava sonhos e sim sua realidade, os sentimentos que a vida lhe causava. Interessa-me compreender as possiveis inspirações, influências, afetos, usos de imagens e artefatos culturais, sejam eles do campo das artes ou não, que constituem seu projeto poético e processo criativo. Um exercício simples no qual me detenho agora é o modo como a artista usou, em determinados momentos de seu processo criativo, imagens. Comento, aqui, detalhes dos quadros Mi vestido cuelga alli (1933, óleo e colagem sobre aglomerado, 45,7 x 49,5 cm) e Autorretrato con collar de espinas y colibrí (1940, óleo sobre tela, $61,25 \times 47 \mathrm{~cm}$ ).

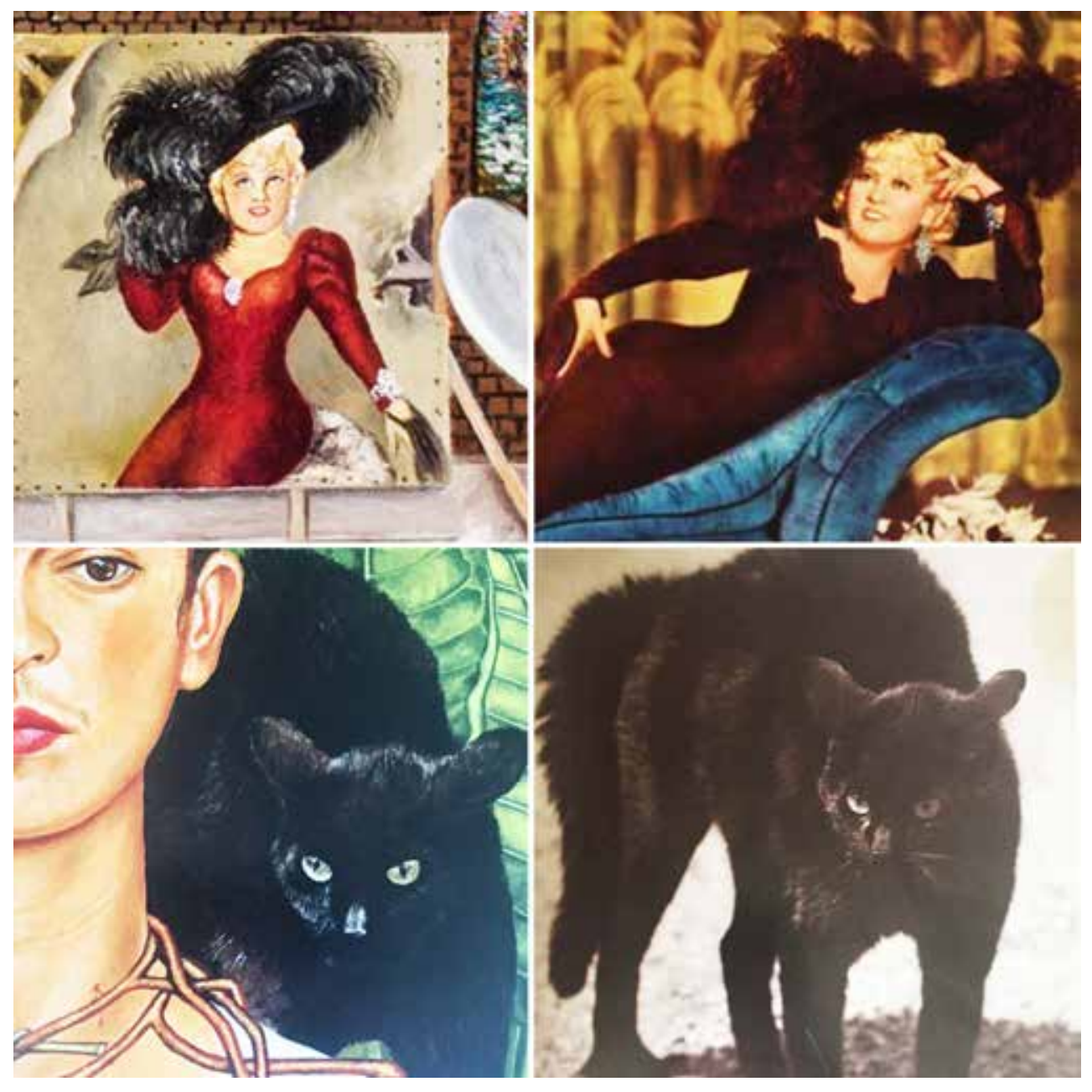

Figura 2: na parte superior, detalhes da pintura Mi vestido cuelga allí (19331938), da coleção FEMSA, Monterrey, México, e do pôster do filme Klondike Annie (Paramount, 1936); na parte inferior, detalhes da pintura Autorretrato con collar de espinas y colibri (1940), da coleção do The Harry Ransom Center, Museum at The University of Texas, Austin, e da fotografia de Martin Munkacsi, do acervo do Museu Frida Kahlo. 
Na parte superior da figura 02, à esquerda, está um detalhe do quadro Mi vestido cuelga allí, onde Frida pinta, centralmente, seu vestido indígena, num varal, pendurado em duas colunas, uma sustentando um vaso sanitário e a outra uma taça/troféu. No entorno do vestido estão imagens do contexto industrial e capitalista estadunidense como fábricas, uma bomba de gasolina, um telefone, um templo grego/banco com um gráfico da bolsa de valores em sua escadaria, a estátua da liberdade, um navio e o porto por onde chegam (e por vezes ficam detidos) os imigrantes, uma igreja que tem um vitral no qual o cifrão, símbolo monetário, se forma atrelado a uma cruz. No lado esquerdo do quadro, aparece uma imagem da atriz norte-americana Mae West (1893-1980), semelhante às imagens de promoção do filme Klondike Annie (1936), conforme o detalhe à direita, na figura 02. No quadro, Frida pintou a imagem de Mae West como um pôster meio rasgado, despregando-se do suporte, mas que ainda exala o glamour e a sensualidade com que a atriz aparecia nos filmes. Uma espécie de Marilyn Monroe, loira fatal, porém mais vivaz e esperta com homens e negócios. Mi vestido cuelga alli é um dos raros quadros onde Frida trabalhou com colagem. Na parte inferior do quadro é possivel ver diferentes imagens, em preto e branco, de manifestações, grandes agrupamentos de pessoas e até pelotões de soldados em marcha. Imagens recortadas, juntadas e coladas. Sobre essas multidões paira o vestido de Frida pendurado.

$\mathrm{Na}$ parte inferior da figura 02, estão um detalhe do quadro Autorretrato con collar de espinas y colibri e uma imagem da foto de um gato preto eriçado, feita pelo fotógrafo húngaro Martin Munkacsi, sem data precisa, que pertence à coleção pessoal de fotos de Frida, preservada no Museu Frida Kahlo. Diferente da imagem de Mae West, que não se tem uma precisão exata acerca de qual imagem Frida utilizou como modelo no seu processo criativo, a imagem do gato preto parece ter sido exatamente reproduzida por Frida em seu autorretrato. Há diversos outros momentos de seu processo criativo em que utiliza imagens e artefatos culturais. São fotografias suas, de familiares, conhecidos e clientes; imagens de esculturas pré-hispânicas que tinha em seu jardim; peças de artesanato popular que colecionava; seus próprios vestidos; seus corsets ortopédicos; sua própria imagem refletida num espelho, nos seus muitos autorretratos; seus macacos, papagaios e periquitos, gato, cachorros e veado de estimação; entre outros elementos que constituíam seu cotidiano, sua cultura visual.

Os modos como Frida Kahlo usava imagens e demais artefatos culturais em seu trabalho artístico pode ser fruto de sua incontinência aos sistemas das artes, não se filiando a nenhuma escola ou corrente pictórica. Frida foi uma artista autodidata que incorporou sua cultura, seu amor pelo México, seu cotidiano e, especificamente, suas experiências corporais, dores e prazer, físicos e sentimentais, em seu processo criativo. Descobrir, em nosso processo criativo de dança, através das imagens de Frida, os modos como ela própria usou imagens em seu processo criativo de pintura, tem sido uma experiência prazerosa e desafiadora, que possibilita compreender entrelaçamentos entre criação e pesquisa, criação artística e construção de conhecimentos.

\section{Relação corpo - imagem no processo criativo de FeridaCalo}

Os procedimentos criativos utilizados no LICCDA fazem parte do conjunto de compreensões e práticas da dança contempop (BERTÉ, 2015), uma proposição de criação artística centrada na relação corpo - imagem. Nos meandros da dança contempop, a imagem é compreendi- 
da sob três aspectos: imagem artefato com a qual o corpo se relaciona em diferentes espaços culturais, conforme as reflexões de Martins (2007), no campo de estudos da cultura visual; imagem como ideia que tece e constitui a mentecorpo, em proximidade com os estudos neurocientíficos de Damásio (2009); e imagem como ação do corpomente, de acordo com as proposições de Bittencourt (2012), nos entrelaçamentos que faz entre os campos da dança, da comunicação e da semiótica. Na relação com as imagens artefato, os corpos acionam imagens e ideias que se conectam a e/ou impactam imagens ações. Essa trama de imagens no corpo não acontece com hierarquias, nem com uma ordem específica capaz de identificar início, meio e fim. A imagem artefato pode lançar-se direto para uma imagem ação, assim como a imagem ideia pode emergir de uma imagem ação, ou vice-versa.

O processo criativo de FeridaCalo iniciouse no segundo semestre do ano de 2014 e consistiu, inicialmente, em que cada dançarino escolhesse uma imagem de Frida Kahlo com que mais se identificasse, de qualquer procedência, fonte, suporte, e trouxesse para os encontros de criação. Apareceram imagens buscadas no google, em livros de arte e revistas. Eram reproduções de fotografias de Frida Kahlo, de pinturas e desenhos criados pela artista e imagens que outros artistas, conhecidos e anônimos, criaram inspirados no universo estético da pintora. Conforme narra o documentário Especial Interkahlos, ${ }^{13}$ o processo de criação teve início com diferentes questionamentos - inspirados nos procedimentos criativos da

13 Especial Interkahlos é um curta-metragem criado no ano de 2016, pela TV Campus e pelo Laboratório Investigativo de Criações Contemporâneas em Dança (LICCDA), da Universidade Federal de Santa Maria. Documenta o processo criativo do espetáculo e intervenção de dança FeridaCalo, baseado em imagens da pintora mexicana Frida Kahlo. Especial Interkahlos pode ser acessado pelo link: <https://www.youtube. com/watch?v=NwY4q-M08OM>. coreógrafa Pina Bausch - para instigar a percepção do dançarino sobre a imagem, ou seja, a relação corpo - imagem: o que a imagem the diz? O que você diz sobre a imagem? o que você diz para a imagem? O que a imagem diz sobre você?

Para alguns, as perguntas foram de fácil compreensão ao passo que, para outros, esse processo de diálogo com a imagem causou estranhamentos. A proposta consistia em que os dançarinos, ou intérpretes-criadores, tentassem responder as perguntas não com palavras, mas com movimentos, gestos, ações. As respostas - frases ou sequências de movimentos - tanto poderiam acontecer através da reconstrução das poses e formas vistas na imagem como por meio de outras possibilidades intuitivas, emocionais e imaginativas de criar movimentos motivados por essa relação de diálogo e confronto com a imagem. Como coreógrafo, ou melhor, como coreógrafo DJ desse processo, meu trabalho consistiu em orientar o grupo na mixagem, junção, colagem, aceleração, edição dos movimentos criados. Como os estudantes, eu também fui um intérpretecriador, criando movimentos e dançando com eles. A partir do material de movimento levantado nessa primeira etapa do processo e dos possiveis direcionamentos dramatúrgicos que daí emergiram, acrescentei no processo outras imagens de Frida com as quais me identifico. Sugeri imagens específicas para determinados dançarinos, com o intuito de desafiá-los a moverem-se a partir de imagens que provinham das minhas identificações. E os resultados disso foram surpreendentes.

Como em FeridaCalo, as imagens de Frida usadas no processo criativo não aparecem em cena, aqui também não explicito as imagens trazidas pelos dançarinos e aquelas que sugeri durante o percurso do processo criativo. Algumas delas, talvez, sejam identificáveis nas cenas, afinal, Frida Kahlo e determinadas 
imagens suas têm passado por um processo avassalador de reprodução técnica e propagação viral, tornando-se facilmente reconhecidas. Já outras dessas imagens, a maioria delas, passou por um processo de refuncionalização e transformação por meio da percepção e da elaboração criadora do grupo. 0 foco do processo criativo é justamente esse: exceder as imagens, transformá-las, realizá-las de outras formas.

Essa forma de processo criativo em dança, que tenho chamado de dança contempop, é um caminho crítico, criador e performativo, que se dá a partir da relação dos corpos com imagens popularizadas nos diversos interstícios do campo cultual contemporâneo. Os procedimentos da dança contempop surgem de imbricações entre os campos da dança e da cultura visual, interessando-se por diferentes tipos de imagens artísticas, midiáticas, da propaganda, do cinema, da televisão, de livros, da internet e de diferentes suportes. O enfoque está nas relações afetivas que os corpos estabelecem com as imagens, atravessando os modos como essas relações podem impelir ou impedir a autonomia em seus modos de se (mo)ver. Os afetos impactam o agir humano, conforme argumenta o filósofo Spinoza (2013). Na dança contempop, importa pensar sobre "como" essas imagens e afetos impactam os corpos: de maneiras fetichistas e alienadoras? De formas mágicas e rituais? De modos críticos, criativos e performativos? A dança contempop pretende-se um modo de ressignificar imagens com as quais nos relacionamos em nosso cotidiano.

Até chegarmos no atual formato de FeridaCalo, outros experimentos como a intervenção artística Me Kahlo (2015) e o trabalho em processo Me Kahlo... Sashay Away (2015) foram levados a público, em diferentes espaços da cidade de Santa Maria, como escolas, rodoviária, shopping, praças e teatro. Essas obras possí- veis, que ficaram no percurso do processo, e as inusitadas reações e opiniões recebidas de diferentes espectadores possibilitaram retomadas, revisões, abandonos, aprofundamentos e intensificações de diferentes partes e elementos que compõem a narrativa desse trabalho artístico. Coincidentemente, como a narrativa do filme Moonlight, a narrativa de FeridaCalo é composta por três partes ou quadros: "desfile", "drama" e "celebração". Sem narrador e sem libreto, o conjunto dos elementos cênicos (música, figurino, objetos, espaço) que se relaciona com o movimento dos corpos, e a instigante visualidade que tempera essas relações, estabelecem uma dramaturgia e uma narrativa emergidas dessa construção e não de conceitos alheios ao processo criativo.

$\mathrm{Na}$ figura 3, estão imagens de cenas dos três quadros que compõem a narrativa de $\mathrm{Fe}$ ridaCalo: a primeira imagem, à esquerda, compõe o quadro "celebração", criado com imagens onde Frida se refere à cultura mexicana, a rituais astecas e a uma espécie de cosmologia e amor universal. Nesse quadro, o último a compor a narrativa do espetáculo, a movimentação estabelece-se como uma celebração latino-americana, feminista, cálida e irreverente. No alto, à direita, uma imagem do quadro "desfile", que abre a narrativa, onde os corpos mostram-se, primeiramente, como imagens sem rosto, cobertos por tonalidades fortes e peles floridas. Esse quadro foi criado com imagens nas quais Frida pinta animais, transmutase em forma de animal como imagem exótica e ao mesmo tempo ferida, posa para fotografias, exibe suas vestimentas, seus penteados decorados com flores, se faz um corpo notável que edita suas identidades e imperfeições físicas. A última imagem, na parte inferior, à esquerda, é do quadro "drama", criado com imagens onde Frida se refere às suas dores, doenças, sofrimentos, aos corsets ortopédicos usados para restabelecer o alinhamento, movimento 
e o equilíbrio de sua coluna vertebral. Nesse quadro, os dançarinos foram desafiados a moverem-se usando corsets artesanais, pouco flexíveis, quase como um impedimento do movimento, gerando imagens tensas e emblemáticas.

Figura 3: Espetáculo e intervenção de dança FeridaCalo (2016). Criação do Laboratório Investigativo de Criações Contemporâneas em Dança (LICCDA), direção de Odailso Berté. Fotografias de Joana Günther.

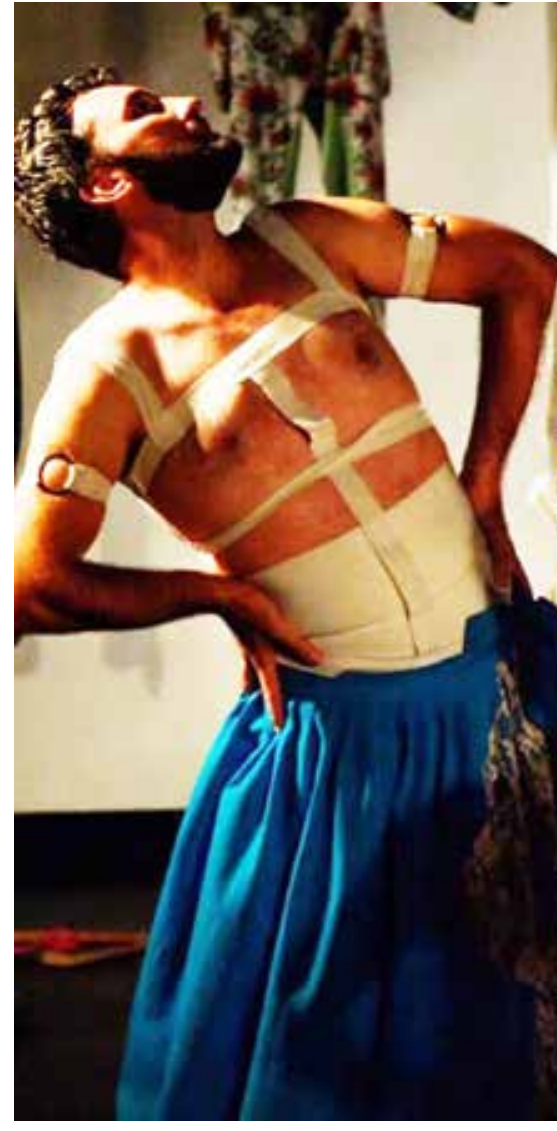

Conforme a reflexão de Lisboa Filho (2016), na crítica ao espetáculo FeridaCalo: ${ }^{14}$

A arte contribui para a mediação do nosso processo existencial. Um espetáculo com tamanha vibração e intensidade, que, aliás, era traço marcante da personalidade de Frida [...]. A arte nos permite exercer a cidadania, nos aguça os sentidos, nos torna mais críticos e reflexivos. Talvez, por isso, a arte incomode a outros, que negligenciam o investimento em políticas públicas culturais. Talvez, porque nos tornamos

14 A crítica do Espetáculo e intervenção de dança FeridaCalo pode ser acessada na íntegra pelo link: < https:// claudemirpereira.com.br/2016/12/critica-feridacalo -produto-e-processo-espetaculo-empolgante-quefaz-justica-a-sua-inspiradora-frida-khalo/>.

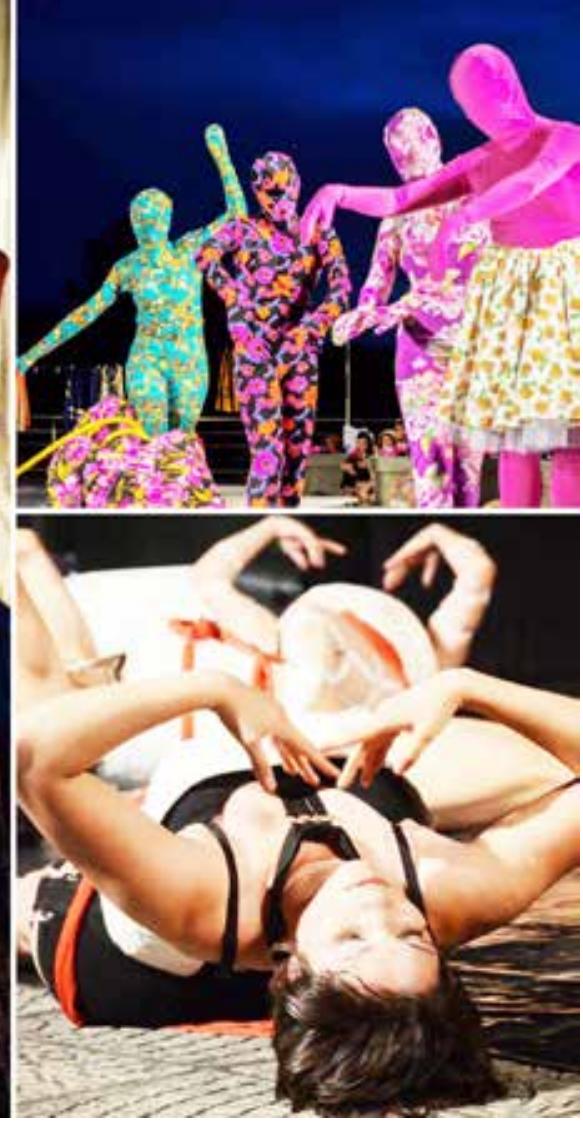

mais cônscios, menos subjugados e mais fortes para lutar.

Estreado na esplanada da Biblioteca Central da Universidade Federal de Santa Maria e reapresentado no largo do Museu de Arte de Santa Maria (MASM), FeridaCalo tem buscado intervir em espaços públicos de movimento, convivência e circulação de corpos. $O$ ato de intervenção, de promover um acontecimento estético no cotidiano de espaços onde não se espera uma apresentação artística, tem nos feito, professores e estudantes, pensar sobre o espaço da arte na sociedade e sobre que formas e modos de arte estamos ensinando den- 
tro da universidade pública e que arte queremos construir e levar a público; refletir sobre as intervenções socioculturais e políticas que a arte pode fazer; conjecturar acerca das interpelações que a arte pode fazer ao imaginário individual e coletivo; perseguir e estreitar as relações entre artes, histórias de vida, experiências, narrativas e biografias de diferentes corpos e contextos; temer e não desesperançar do presente e do futuro para viver como artista e professor de artes. A arte e, particularmente, a arte que consegue existir desvinculada dos grilhões das belas artes, associando-se à educação, à pesquisa, a diferentes contextos e práticas socioculturais e populares e a referentes pós-modernos transgressores, não goza de privilégios estéticos, econômicos e midiáticos. A resistência ainda se mostra como potente estratégia para uma práxis artística engajada, pós-revolucionária, ferida, ousada, popular e impregnada de afetos, que, como Frida, precisa repetir e exceder a própria imagem para seguir ressuscitando mesmo após a morte.

No contexto da reflexão sobre como a fridomania pode ser vista como uma moda e sobre como o conceito Frida Kahlo inclui e transcende a fridomania, Monsiváis (2004, p. 29, tradução nossa) afirma que "os artistas que utilizam Frida Kahlo podem ou não 'refuncionalizá-la' na perspectiva pós-moderna, ou usá-la como recurso intertextual".15 Nossa perspectiva, no processo criativo de FeridaCalo, tem sido refuncionalizar, reinterpretar e exceder as imagens que usamos como referência. Elas não aparecem diretamente na cena, se aparecem, são como estilhaços, alusões e suaves menções manipuladas pela percepção e pelo ato criador dos intérpretes-criadores. Como DJs de nós mesmos, usamos e editamos imagens, de modo crítico, criador e performativo, configurando uma dança que é o modo de expressarmos, em movi-

15 No original: “[...] los artistas que utilizan a Frida Kahlo pueden o no 'refuncionalizarla' en la perspectiva posmoderna, o usarla como recurso intertextual". mento - imagens ações, aquilo que pensamos e sentimos acerca das imagens de Frida.

\section{Imagem e performatividade no ensino e criação de dança}

$\mathrm{Na}$ relação corpo-imagem, cara à proposição da dança contempop, emerge a problemática da performatividade das imagens e das narrativas visuais com as quais nos confrontamos, queiramos ou não. A partir das reflexões sobre performatividade de Austin (1990), na filosofia da linguagem, e de Butler (2012), em torno dos discursos normativos que materializam sexo e gênero nos corpos, Acaso (2011) propõe a discussão sobre a performatividade visual. Esta autora enfatiza a urgência de reconhecermos

o poder performativo (transformativo do social) da linguagem visual, uma mudança que nos levaria a entendê-la, para além de um sistema de representação, como uma força de transformação. [...] Talvez tenhamos que escrever um texto que se chame Como fazer coisas com imagens ou As imagens fazem coisas para pôr em discussão o fato de que no mundo em que vivemos, a linguagem visual é o principal sistema que está transformando a realidade, performando nosso corpo, nossas ideias, nossos hábitos. É ela que nos obriga a operar-nos, a mutilar-nos, a autotorturar-nos. Longe de ser um mero instrumento de comunicação, a linguagem visual é a ferramenta que performa a realidade. E para poder refletir sobre seu poder, os museus de artes visuais (e mesmo a escola, a universidade ou qualquer outro espaço educativo) hão de começar a assumir o papel protagonista do visual na realidade externa ao museu e, portanto, hão de incorporá-la dentro. ${ }^{16}$ (ACASO, 2011, p. 40, tradução nossa)

16 No original: "[...] el poder performativo (transformativo de lo social) del linguage visual, un cambio que nos llevaría a dejar de entenderlo como un sistema de representación y entenderlo como una fuerza de transformación. [...] Quizá tengamos que escribir un texto que se llame Cómo hacer cosas con imágenes - Las imágenes hacen cosas para poner encima de la mesa que, en el mundo en el que vivimos, es el linguaje visual el principal sistema que está transformando la realidade, performando nuestro cuerpo, nuestras ideas, nuestros hábitos, que es el que nos obliga a operarnos, a mutilarnos, a autotorturarnos. 
Esta é uma reflexão que vem se tornando cada vez mais cara e necessária, após reconhecermos que as imagens não são veículos inócuos, ilustrações ingênuas, mas agentes culturais que performam os espectadores, que regulam suas subjetividades, identidades e identificações. A urgência desse reconhecimento de como agem as pedagogias culturais da imagem, passa pela responsabilidade e pelos papéis socioculturais das artes, das universidades, dos museus, das escolas. Conforme propõem os estudos e práticas da educação da cultura visual (MARTINS; TOURINHO, 2015), esse reconhecimento deve levar à articulação de estratégias pedagógicas para se trabalhar justamente nas brechas ou falhas dos sistemas socioculturais performativos das imagens. Conforme Butler (2012), nas práticas de repetição das normas performativas, nem todos os corpos fazem isso perfeitamente, da forma com a lei objetiva. Há excessos, subversões, incompletudes, discrepâncias e falhas entre as ações dos corpos e as normas. Nessas relações de repetição, atualização, negociação e resistência entre os corpos e as leis, emergem possibilidades de recontextualizar condições preestabelecidas e articular configurações culturais alternativas.

Nós, corpos, não somos meros depósitos de informações, conteúdos e imagens, ou, meros bonecos, "vodus" predestinados e submetidos à manipulação e à arbitrariedade de leis inventadas por outros corpos. Compartilho da compreensão de corpomídia (KATZ; GREINER, 2005) que entende o corpo como contaminado e contaminador do ambiente, que recebe, reconstrói e coloca informações no mundo. As

Lejos de ser un mero instrumento de comunicación, el linguage visual es la herramienta que performa la realidad. $Y$ para poder reflexionar sobre su poder, los museos de artes visuales (lo mismo que la escuela, la universidad o qualquiera otro enclave educativo) han de empezar a asumir el rol protagónico de lo visual en la realidad externa al museo y, por lo tanto, han de incorporarla dentro". informações que chegam são transformadas em corpo, entram em contato com aquelas que já estão, criando atritos, afeições e negociações, reconstruções. Essas trocas, que constituem as experiências do corpo, contribuem para a transformação do seu design, estrutura, percepção, movimento, formação, em termos biológicos e culturais. o corpo é o que vai se aprontando, é o resultado provisório das relações contínuas natureza-cultura. Corpo é processo, ação, trânsito entre natureza e cultura. Desse modo, o corpo pode ser visto como mídia desses processos, trocas e contaminações.

As imagens são performativas, elas têm um poder de transformação e não apenas de representação, no sentido de que elas (per)for$\mathrm{mam} /($ trans)formam a vida e as relações dos corposmídia. As imagens contaminam. Acreditando nas possibilidades dos corposmídia alargarem as brechas e falhas das normas reguladoras, e assim excederem, reconstruírem e ressignificarem imagens, informações e discursos, trabalhamos na perspectiva da dança contempop. O exercício criativo de elaborar movimentos com imagens de Frida passa por questionar-se sobre: o que diz a imagem? 0 que eu digo sobre a imagem? 0 que a imagem diz de mim? O que a imagem diz do contexto/ momento onde vivo? Que experiências, acontecimentos, pessoas ela me faz recordar?

Discutindo como as normas reguladoras do sexo operam de uma maneira performativa para constituir a materialidade dos corpos, materializar o sexo do corpo, Butler (2012, p. 18, tradução nossa) argumenta que "a performatividade deve ser entendida não como um 'ato' singular e deliberado, mas, como a prática reiterativa e referencial mediante a qual o discurso produz os efeitos que nomeia". ${ }^{17}$

17 No original: “[...] la performatividad debe entenderse, no como un 'acto' singular y deliberado, sino, antes bien, como la práctica reiterativa y referencial mediante la cual el discurso produce los efectos que nombra". 
Numa espécie de redução interteórica (CHURCHLAND; CHURCHLAND, 1995), pela qual se desloca um conceito de uma área para outra, tenho tentado compreender essa engenhosidade da performatividade - realizar aquilo que nomeia - como estratégia de criação e compreensão da dança. Fazendo uma analogia, penso que Frida, em seu processo de criação, produzia imagens performativas. Sua pintura não representa sua realidade, mas a transforma, a excede; realiza ou reelabora a experiência vivida de outra forma. Como adentrar as práticas reiterativas e performativas das imagens e narrativas, ao produzirem os efeitos que nomeiam, provocando falhas e subversões nessas estruturas relacionais? Como os processos de criação artística podem vir a ser espaços de práticas reiterativas, referenciais e performativas, onde imagens servem como referências a serem excedidas e subvertidas de modo crítico e criador?

Com Setenta (2008, p. 31-32), tenho buscando, junto a outros corpos, fazer-pensar uma dança performativa, ou seja, "um fazer-dizer que não apenas 'comunica' uma ideia, mas 'realiza' a própria mensagem que comunica", compreendendo "o corpo que dança como um inventor de modos próprios de proferir ideias". Propagadas pelos diferentes âmbitos da cultura pop e da arte, e trazidas pelos dançarinos para o processo de criação, as imagens de Frida passam por um crivo crítico, criador e performativo. Buscamos configurar uma dança que não é representativa, mas performativa, ou seja, que não representa as imagens de Frida, mas as (trans)forma, as (per)forma - as realiza de outras formas.

Investimos na possibilidade dos corpos subverterem seus referenciais, nesse caso, excederem as imagens de Frida, realizarem de outras formas aquilo - as imagens - a que se referem. 0 corpo se relaciona com a imagem encontrando estratégias para proferir a si pró- prio. Nesse sentido, não cabe entender, como dança, apenas os repertórios de movimentos prontos, habituais e já conhecidos, tão usados para comunicar e contar diferentes histórias. Nestas estratégias performativas está o desafio do corpo inventar modos próprios de fazer-dizer o que sente, pensa, quer, imagina, saindo do lugar comum de ser apenas veículo de uma mensagem, para ser, ele próprio - o corpo - mensagem. Conforme Setenta (2008, p. 45), "para produzir esse discurso só seu, o corpo trabalha experimentando/testando as informações, movimentando-as". Dança é corpo movendo ideias.

Nos processos criativos da dança contempop, compreendida como uma forma de dança performativa, os corpos atam, no fluxo de movimento, imagens-artefatos, imagens-ideias, imagens-ações. Ao dançarem, não há como distinguir com exatidão essas modalidades da imagem, dado que o processo criativo - conjunto de ações organizativas do corpo - é como um processador que mistura, atrela, amalgama artefato-ideia-ação. 0 que se dá a ver, a dança, é esse complexo de imagens, encharcadas de experiências, que deslizam no fluxo de movimento do corpo.

Investimos numa dança performativa não para performar as ideias, os hábitos, as realidades dos corposmídia, materializando neles dogmas, morais e normas reguladoras. Em vez disso, uma dança performativa para performar com os corpos outras formas de ser e se mover, para articular com eles configurações culturais alternativas, subversivas e excedentes. Nesses fazeres, Frida tem sido um conceito e contexto a ser estudado; uma imagem amiga e multifacetada a ser excedida; um corpo - natureza viva - a ser poeticamente exumado, contextualizado, sentido; um processo de criação artística a ser investigado.

Trabalhar com imagens de Frida a partir das reflexões e perspectivas da estetização da 
cultura (AGUIRRE, 2011), das pós-produções na arte contemporânea (BOURRIAUD, 2009), das pedagogias culturais (GIROUX, 1999), da educação da cultura visual (MARTINS; TOURINHO, 2015) em correlação com a dança contempop (BERTÉ, 2015), tem sido não só prazeroso como desafiador. De heroína a virgem dolorosa, Frida é uma imagem que, nos processos artísticos e pedagógicos que tenho participado e observado, tem estimulado corpos, dançarinos, intérpretes-criadores e estudantes, à autoexpressão, à valorização de diferenças raciais, de gênero e orientação sexual, à reflexão sobre arte e política, à correlação entre arte, experiência, imagem e narrativas de histórias de vida.

Reafirmo o desafio das artes, escolas, universidades, teatros, secretarias de cultura e museus assumirem um papel protagonista de compreenderem que são algumas entre tantas corporações e corpos a proliferar imagens. Assim, têm importantes contribuições pedagógico-culturais a dar, não no sentido de demonizar o que tem lhes escapado na enxurrada da estetização cultural, para tentar reaver o poder e o controle perdido sobre tais artefatos e experiências. Mas, no sentido de compreender e dialogar com os diferentes corpos e corporações que propagam e usam imagens, construindo formas de acesso mais democráticas às narrativas e imagens artísticas, interconectando e incorporando seus acervos ao cotidiano e experiências dos corpos, auxiliando-os a construir formas críticas, criativas e performativas, de ver e se (mo)ver no contexto contemporâneo.

A trama de narrativas imagéticas e conceituais, aqui articulada, leva-me outra vez à aula de dança de Chiron, da narrativa fímica de Moonlight, e a questões em torno do ensino das artes, e especificamente de dança, hoje. 0 ensino de artes compete com a pedagogia cultural da performatividade da imagem, e nessa competição, sai desfavorecido. A preponderân- cia de imagens da cultura pop, por exemplo, na afetividade de estudantes de diferentes niveis de aprendizagem é consideravelmente mais incisiva que os conteúdos ensinados nas aulas de artes. Nas aulas de dança, em nível de graduação, onde atuo, é notável o interesse de diferentes alunos por imagens idealizadas de dança, virtuosas, vigorosas e sentimentalistas, o apreço pelas danças prontas, com sequências de passos bem demarcados para serem transmitidos, decorados e executados com precisão e sincronia, batendo continência às notas e oscilações de uma música.

Nas aulas de processos criativos, é com insistência que as propostas pós-modernas e contemporâneas de dança, calcadas na expressividade e no potencial criador do corpo, vão sendo, aos poucos, aceitas, apreciadas, aprendidas e usadas. No ensino de dança, ainda ronda o fantasma da tradicional compreensão tecnicista de dança. O fantasma do rigor e do virtuosismo do balé clássico ainda persegue e, por vezes, entra em atrito com propostas de ensino e criação que, antes da execução de movimentos, investem na percepção, experimentação e exploração de movimentos, com o intuito de ampliar a consciência corporal e estimular o potencial criador do corpo artista.

Propostas e processos criativos como os do LICCDA não têm pleno sucesso de audiência. Passam por conflitos, críticas e dissidências. Mas também desfrutam da adesão de um grupo significativo - não tanto pela quantidade e despojado, disposto a aprofundar o conhecimento em dança e ampliar as possibilidades metodológicas, pedagógicas, criadoras e investigativas. Refuncionalizar e exceder o poder performativo de imagens e narrativas de dança, do que é técnica, de corpo, de homem, de mulher, do que é bonito, do que é política e pedagogicamente correto, do que é normal e do que é aberração, é ainda um desafio a ser enfrentado por longos e longos anos. Nesse 
sentido, não se trata de demonizar as imagens de dança que os estudantes trazem consigo, por mais tradicionais e tecnicistas que pareçam, mas auxiliá-los num processo de transformação e reconstrução. Há que se seguir investindo e insistindo em propostas interpe-

\section{Referências}

ACASO, M. Del paradigma modernista al posmuseo: seis retos a partir del giro educativo (¿Lo intentamos?). In: ACASO, M. Perspectivas. Situación actual de la educación en los museos de artes visuales. Barcelona: Ariel, 2011. p. 36-43.

AGAMBEN, G. 0 que é o contemporâneo? E outros ensaios. Chapecó: Argos, 2009. 92 p.

Profanações. São Paulo: Boitempo, 2007. 96 p.

AGUIRRE, I. Cultura visual, política da estética e educação emancipadora. In: MARTINS, R.; TOURINHO, I. Educação da cultura visual: conceitos e contextos. Santa Maria: Editora UFSM, 2011. p. 69-111.

AUSTIN, J. L. Quando dizer é fazer: palavras e ação. Porto Alegre: Artes Médicas, 1990. 136 p.

BARTRA, E. Frida Kahlo en el siglo XXI. In: ORELLANA, M. Frida Kahlo, un homenaje. Ciudad de México: Fideicomiso Museo Dolores Olmedo y Fideicomiso Museos Diego Rivera - Frida Kahlo (Banco de México), 2004. p. 34-53.

BERTÉ, O. Dança contempop: corpos, afetos e imagens (mo)vendo-se. Santa Maria: Ed. UFSM, 2015. 200 p.

Corpo e experiência no processo criativo de Frida Kahlo: conexões entre dança e cultura visual. Revista Digital do Laboratório de Artes Visuais (LAV). v. 9, n. 3, p. 60-85, set./dez. 2016. Disponível em: <https://periodicos.ufsm.br/revislav/article/ view/24044>. Acesso em: 05 mar. 2017.

BITTENCOURT, A. Imagens como acontecimentos: dispositivos do corpo, dispositivos da dança. Salvador: EDUFBA, 2012. 93 p.

BOURRIAUD, N. Pós-produção: como a arte reprograma o mundo contemporâneo. São Paulo: Martins, 2009. 112 p. ladoras que são capazes de mover os corpos a outras compreensões, visões, imagens, narrativas. Propostas artísticas e pedagógicas que possibilitem aos corpos recriar experiências... Para que a vida transpareça na dança... Para que a dança transpire vida.

BUTLER, J. Cuerpos que importan: sobre los límites materiales y discursivos del sexo. Buenos Aires: Paidós, 2012. 346 p.

CERTEAU, M. A invenção do cotidiano: 1. Artes de fazer. Petrópolis, RJ: Vozes, 2012. 316 p.

CHURCHLAND, Paul; CHURCHLAND, Patrícia. Intertheoric Reduction: a neuroscientist's field guide. In: Nature's imagination. New York: Oxford University Press, 1995. p. 64-77.

DAMÁSIO, A. 0 mistério da consciência: do corpo e das emoções ao conhecimento em si. São Paulo: Companhia das Letras, 2009. 474 p.

DEL CONDE, T. Frida Kahlo: la pintora y el mito. Ciudad de México: Plaza y Janés, 2002. 147 p.

ESPECIAL Interkahlos. Direção e produção Anaqueli Rubin e Carine Provedello. Direção artística Odailso Berté. TV Campus e Laboratório Investigativo de Criações Contemporâneas em Dança (LICCDA). Universidade Federal de Santa Maria, 2016. (24 min.). Disponivel em: <https://www.youtube.com/watch?$v=$ NwY4q-M080M)>. Acesso em: 11 set. 2016.

ESTRADA, G. La construción de identidad. In: LAMBERT, M. (Coord.). Todo el universo Frida Kahlo: el mundo México. Ciudad de México: Vogue México y Latinoamérica, 2013. p. 27-37.

FERIDACALO. Intervenção de Dança. Direção de Odailso Berté. Criação do Laboratório Investigativo de Criações Contemporâneas em Dança (LICCDA). Curso de Dança - Licenciatura da Universidade Federal de Santa Maria (UFSM). Duração 60'. 2016.

FRIDA. Direção de Julie Taymor. Estados Unidos: Imagem Filmes. Miramax Internacional, 2002. 1 DVD (123 min.): DVD, NTSC, color. 
GIROUX, H. A cultura popular como pedagogia do Prazer e Significado: descolonizando o corpo. In: Giroux, H. Cruzando fronteiras do discurso: novas políticas em educação. Porto Alegre: Artmed, 1999. p. 211-240.

GREINER, C. 0 corpo: pistas para estudos indisciplinares. São Paulo: Annablume, 2005. 152 p.

GÓMEZ, N. U. Frida Kahlo, la metamorfosis de la imagen. In: HERNÁNDEZ, A. S. (Coord.). Frida Kahlo. Ciudad de México: Instituto Nacional de Bellas Artes, 2006. p. 14-24.

HÉRCOLES, R. Corpo e Dramaturgia. In: NORA, S. (Org.). Húmus 1. Caxias do Sul: Prefeitura Municipal de Caxias do Sul/Secretaria da Cultura, 2006. p. 104-111.

HERRERA, H. Frida: a biografia. 4. ed. São Paulo: Globo, 2015. 624 p.

KAHLO, F. O diário de Frida Kahlo: um autorretrato íntimo. 4. ed. Rio de Janeiro: José Olympio, 2015. 282 p.

KATZ. H. O coreógrafo como DJ. In: AMORIM, P. H. (Org.). Lições de dança 1. Rio de Janeiro: Faculdade da Cidade, 1998. p. 11-24.

O corpo como mídia de seu tempo: a pergunta que o corpo faz. Rumos Itaú Cultural Dança, São Paulo: Itaú Cultural, 2004. CD-ROM.

KATZ, H.; GREINER, C. Por uma teoria do corpomídia. In: GREINER, C. 0 corpo: pistas para estudos indisciplinares. São Paulo: Annablume, 2005. p. 125-136.

LAVÍN, M. Frida Kahlo: su obra los ojos de Frida. In: LARA, M. E. Museo Dolores Olmedo. Ciudad de México: Museu Dolores Olmedo Patiño, 2007. p. 200-241.

LISBOA FILHO, F. F. Ferida Calo: produto e processo. Espetáculo empolgante, que faz justiça à inspiradora, Frida Khalo. 2016. Disponível em: <https:// claudemirpereira.com.br/2016/12/critica-feridacalo -produto-e-processo-espetaculo-empolgante-quefaz-justica-a-sua-inspiradora-frida-khalo/>. Acesso em: 05 mar. 2017.

LOUPPE, L. Poética da dança contemporânea. Lisboa: Orfeu Negro, 2012. 404 p.

LOZANO, L. M. Frida Kahlo: Una relectura para conocer el universo estético de la pintora. In: LOZANO, L.
M. (Coord.). Frida Kahlo. Ciudad de México: Landucci, 2007. p. 18-169.

MARTINS, R. A cultura visual e a construção social da arte, da imagem e das práticas do ver. In: OLIVEIRA, M. O. (Org.). Arte, educação e cultura. Santa Maria: Editora UFSM, 2007. p. 19-40.

MARTINS, R.; TOURINHO, I. (Orgs.). Educação da cultura visual: aprender... pesquisar... ensinar... Santa Maria: Editora UFSM, 2015. 296 p.

MITCHELL, W. J. T. O que as imagens realmente querem? In: ALLOA, E. (Org.). Pensar a imagem. Belo Horizonte: Autêntica, 2015. p. 165-189.

MOONLIGHT, sob a luz do luar. Direção de Barry Jenkins. Estados Unidos: Diamond Films, 2017.

MONSIVÁIS, C. De todas las Fridas posibles (una selección mínima). In: ORELLANA, M. Frida Kahlo, un homenaje. Ciudad de México: Fideicomiso Museo Dolores Olmedo y Fideicomiso Museos Diego Rivera - Frida Kahlo (Banco de México), 2004. p. 08-33.

RICO, A. Frida Kahlo: fantasia de un cuerpo herido. 3. ed. Ciudad de México: Plaza y Valdés, 2004. 181 p. RIVERA, D. Frida Kahlo y el arte mexicano. In: LOZANO, L. M. (Coord.). Frida Kahlo. Ciudad de México: Landucci, 2007. p. 233-235.

SALLES, C. A. Gesto inacabado: processo de criação artística. São Paulo: Intermeios, 2014. 186 p.

SETENTA, J. S. 0 fazer-dizer do corpo: dança e performatividade. Salvador: EDUFBA, 2008. 124 p.

SHUSTERMAN, R. Vivendo a arte: o pensamento pragmatista e a estética popular. São Paulo: Ed. 34, 1998. 268 p.

SPINOZA, B. Ética. Belo Horizonte: Autêntica, 2013. $238 \mathrm{p}$.

TIBOL, R. Escritos de Frida Kahlo. Lisboa: Bertrand, 2004. 493 p.

Frida Kahlo an open life. Albuquerque: University of New Mexico, 1993. 230 p.

Recebido em: 03.01.2017

Aprovado em: 20.03.2017 
Odailso Berté é Doutor em Arte e Cultura Visual (UFG), Mestre em Dança (UFBA), Professor dos Cursos de Dança (Bacharelado e Licenciatura) da UFSM e Coordenador do Laboratório Investigativo de Criações Contemporâneas em Dança (LICCDA). e-mail: odailso.berte@ufsm.br

Universidade Federal de Santa Maria (UFSM). Av. Roraima, 1000, prédio 51, Centro de Educação Física CEP: $97105-900$ / (55)3220-8883 